ANATOLIA Anatolia Antiqua

ANTIQUA

Revue internationale d'archéologie anatolienne

XXII | 2014

Varia

\title{
On the Excavations of the Zeus Temple of Alabanda
}

\section{Suat Ateşlier}

\section{(2) OpenEdition}

\section{Journals}

Electronic version

URL: http://journals.openedition.org/anatoliaantiqua/315

DOI: 10.4000/anatoliaantiqua.315

Publisher

IFEA

Printed version

Date of publication: 1 January 2014

Number of pages: 247-254

ISBN: 9782362450136

ISSN: 1018-1946

\section{Electronic reference}

Suat Ateșlier, «On the Excavations of the Zeus Temple of Alabanda », Anatolia Antiqua [Online], XXII |

2014, Online since 30 June 2018, connection on 18 December 2020. URL : http://

journals.openedition.org/anatoliaantiqua/315; DOI : https://doi.org/10.4000/anatoliaantiqua.315

Anatolia Antiqua 


\section{ANATOLIA ANTIQUA ESKI ANADOLU}

\section{XXII}

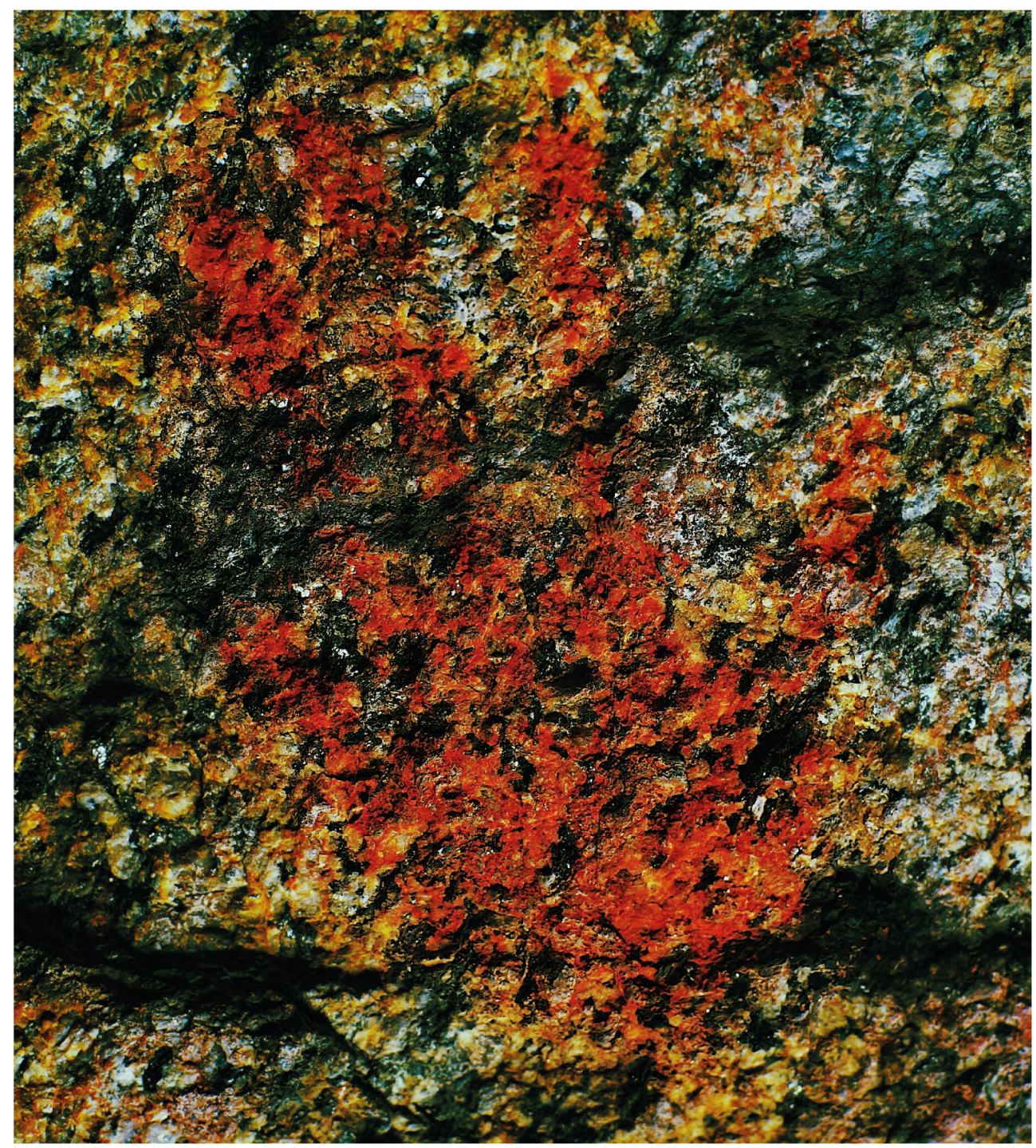

INSTITUT FRANÇAIS D'ETUDES ANATOLIENNES GEORGES-DUMEZIL CNRS USR 3131

DE BOCCARD 


\section{TABLE DES MATIERES}

Emma BAYSAL,

A preliminary typology for beads from the Neolithic and Chalcolithic levels of Barcın Höyük

William ANDERSON, Jessie BIRKETT-REES, Michelle NEGUS CLEARY,

Damjan KRSMANOVIC et Nikoloz TSKVITINIDZE,

Archaeological survey in the South Caucasus (Samtskhe-Javakheti, Georgia):

Approaches, methods and first results

Eda GÜNGÖR ALPER,

Hellenistic and Roman period ceramic finds from the Balatlar Church excavations in

Sinop between 2010-2012

Ergün LAFLI et Gülseren KAN ŞAHİN,

Hellenistic ceramics from Southwestern Paphlagonia

Oğuz TEKIN,

Weights of Lysimachea from the Tekirdağ Museum and various collections

Oğuz TEKIN,

Three weights of Lampsacus

Julie DALAISON et Fabrice DELRIEUX,

La cité de Néapolis-Néoclaudiopolis : histoire et pratiques monétaires

Martine ASSENAT et Antoine PEREZ,

Amida 4. Constance II et Amida

Sencan ALTINOLUK et Nilüfer ATAKAN,

Abrasax: A magical gem in the Istanbul Archaeological Museums

Bahadır DUMAN,

A group of local production Middle Byzantine period pottery from Tripolis:

'Micaceous White Painted Ware'

CHRONIQUES DES TRAVAUX ARCHEOLOGIQUES EN TURQUIE, 2014

Jean-Charles MORETTI,

avec la collaboration de Nicolas BRESCH, Isabel BONORA, Jean-Jacques MALMARY et

Olivier RISS,

Claros, le Temple d'Apollon : travaux réalisés en 2013

Suat ATEŞLIER,

On the excavations of the Zeus Temple of Alabanda 
Olivier HENRY,

avec Ayşe Güliz BİLGIN ALTINÖZ, Jesper BLID, Ömür Dünya ÇAKMAKLI, Andrew DUFTON, Agneta FRECCERO, Linda GOSNER, Ragnar HEDLUND, Pascal LEBOUTEILLER,

Vasilica LUNGU, Felipe ROJAS, Fredrik TOBIN, Baptiste VERGNAUD et

Andrew WATERS,

La mission Labraunda 2013 - Rapport préliminaire

Dominique BEYER, Isabelle CHALIER, Françoise KIRNER,

Françoise LAROCHE-TRAUNECKER et Aksel TIBBET,

Zeyve Höyük - Porsuk. Rapport préliminaire sur la campagne 2013

Çiğdem MANER,

Preliminary report on the first season of the Konya-Ereğli (KEYAR) survey 2013 


\section{Suat ATEŞLİER*}

\section{ON THE EXCAVATIONS OF THE ZEUS TEMPLE OF ALABANDA}

The ancient city of Alabanda stands on the northern slope of the Gökbel Mountain, about $7 \mathrm{~km}$ west of Çine (ancient Marsyas valley), province of Aydın, in the village of Doğanyurt, locality of Araphisar ${ }^{1}$.

The first excavations at Alabanda date from the early $20^{\text {th }}$ century. It was a time when Osman Hamdi Bey was carrying out excavations at the sanctuary of Hekate Lagina. On his way to Lagina he visited Alabanda and suggested that his younger brother Halil Ethem Bey should start archaeological research there ${ }^{2}$.

Halil Ethem Bey started the excavations at Alabanda in the years of $1904-1905^{3}$. In 1904, he focused his attention on the Doric temple (Fig. 1) and published the results in the French CRAI journal ${ }^{4}$. The site was quickly forgotten, until a new research started in the 2000's, under the responsibilities of the Aydın Museum Directorate. The Aydın museum decided not to continue Ethem bey's work on the Doric temple and focused on the Theater and the Apollon Temple area ${ }^{5}$. As the Doric temple did not get any attention for more than a hundred years, the remains that had been uncovered seriously suffered from the lack of protection. In this time span column drums and naos blocks of the building, as seen in the photograph taken by Ethem Bey, tilted and were covered by a thick layer of earth.

Since 2011, a new research and excavation project was put together under my responsibility, which aim was to resume the study of the city and its surroundings. The first results of this new research program have been overwhelming and promising for the years to come. One has, for example, to mention the recent discovery of a remarkable prehistoric rock paintings at Sağlik Köy, near Alabanda (Fig. 2-3). The figures resemble the prehistoric rock paintings found in the Latmos Mountains on the north shore of the former Latmian Gulf ${ }^{6}$. The rock paintings representing the schematized linear figures and a lifesize hand painted in red are a major addition to our knowledge of the early stage of Karia.

In 2011, it was decided that the excavations should start with the continuation of Halil Ethem Bey's work, therefore focusing on the Doric temple.

In the summer of 2011 the naos and pteron of the temple were excavated (Fig. 4-5) ${ }^{7}$. The north side of the building was also cleared by digging up Ethem Bey's excavation dump that was collected north of cella. The excavation of this dump coming from the excavation of the Doric temple revealed a surprisingly rich material, including a very large amount of ceramic sherds as well as gold coins, bringing up as many information on the history and development of the temple.

\section{THE IDENTIFICATION OF THE TEMPLE}

While excavating the cella, Ethem Bey had brought to light a piece of terracotta representing a figurine of Artemis-Hekate, leading him to support the idea that the temple had been dedicated to Artemis $^{8}$. In the recent excavations, however, an altar carrying a labrys on one side and a wreath on the other side was uncovered inside the temenos area (Fig. 6). This important discovery seriously questions the previous identification of the temple as it

* Adnan Menderes Üniversitesi, Fen-Edebiyat Fakültesi, Arkeoloji Bölümü, Aydın/TÜRKIYE.

1) Hirschfeld 1893: 1270; Marchese 1976: 70-71; Bean 1980: 189.

2) Ethem Bey 1905: 443-444.

3) Ethem Bey 1905: 443- 459, Fig. 5-6; 1906: 407-422, Fig. 1; Fowler 1906: 99.

4) Ethem Bey 1905: 450-455; 1906: 407-408. The first excavation season finished on October 26, 1904. The second season began on September 10, 1905

5) Yener 2001: 5-16; 2002: 179-190; 2005: 117-124; 2006: 171-180.

6) Peschlow-Bindokat 2006.

7) Ateşlier 2012: 78-84.

8) Ethem Bey 1905: 455; Bean 1980:159. 

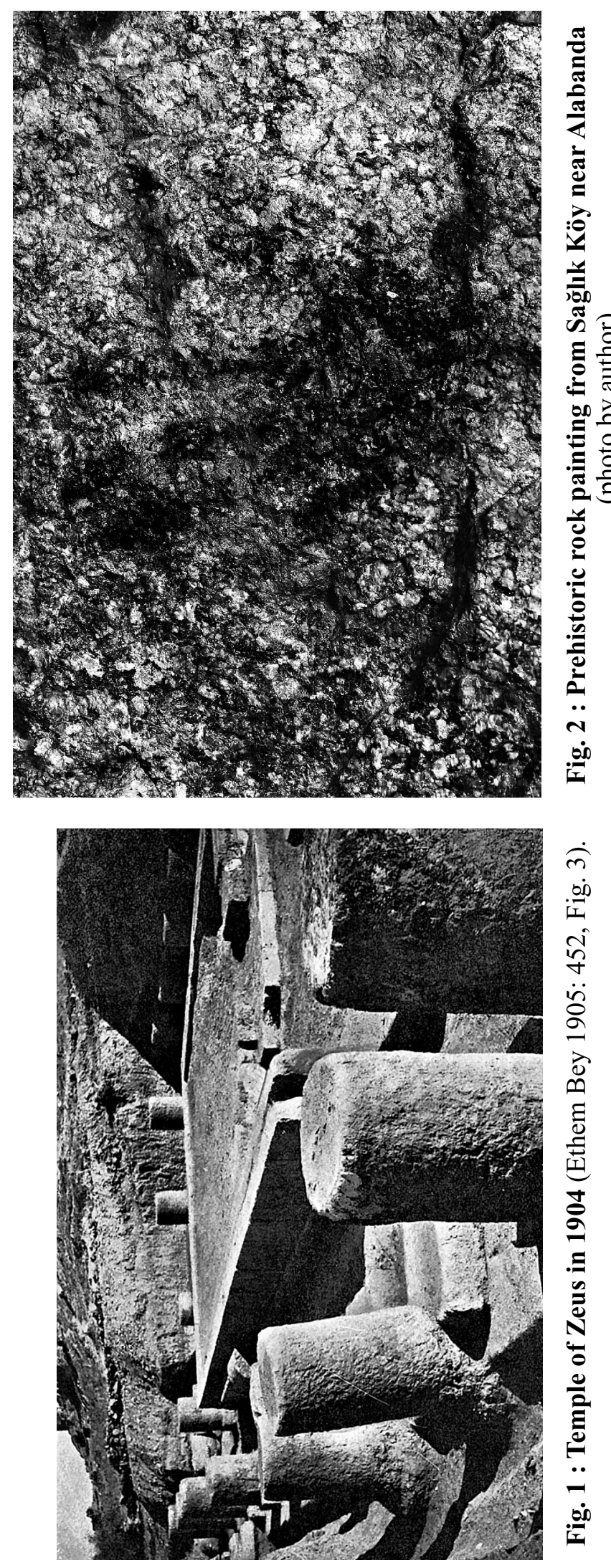
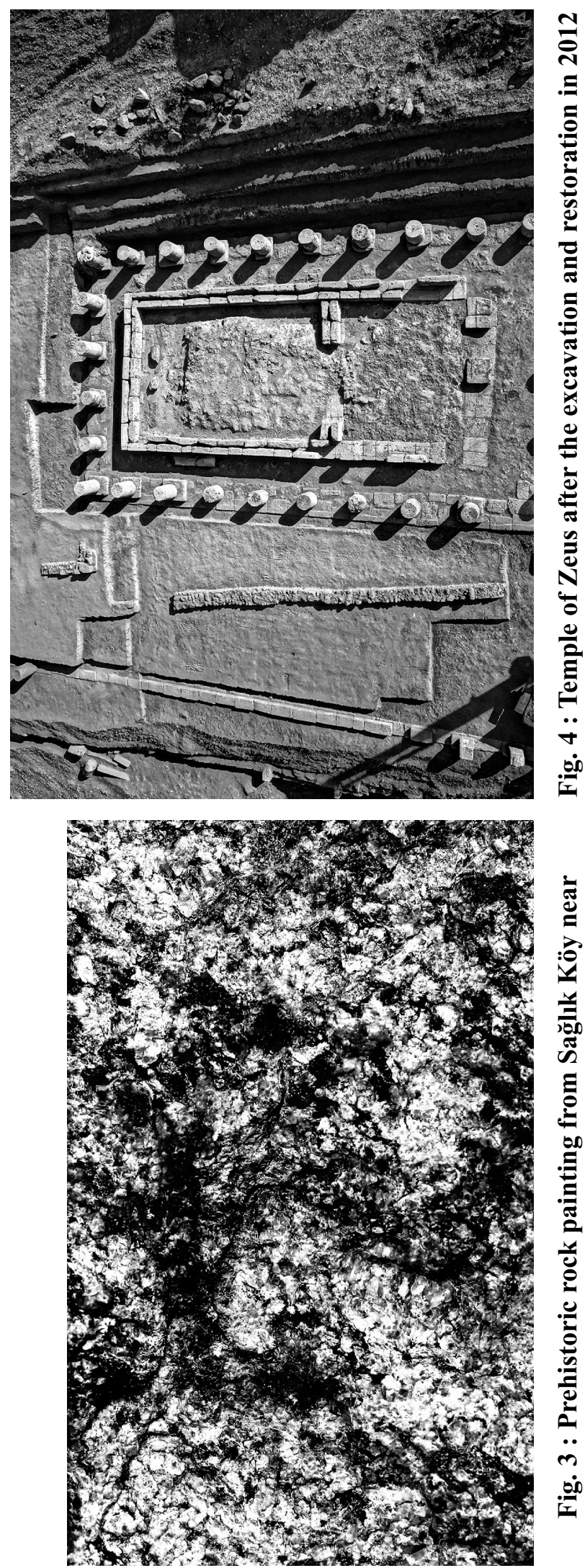

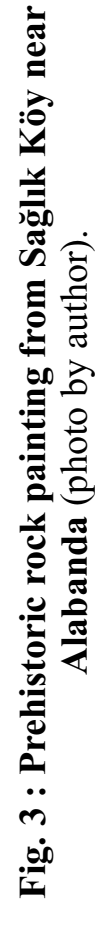




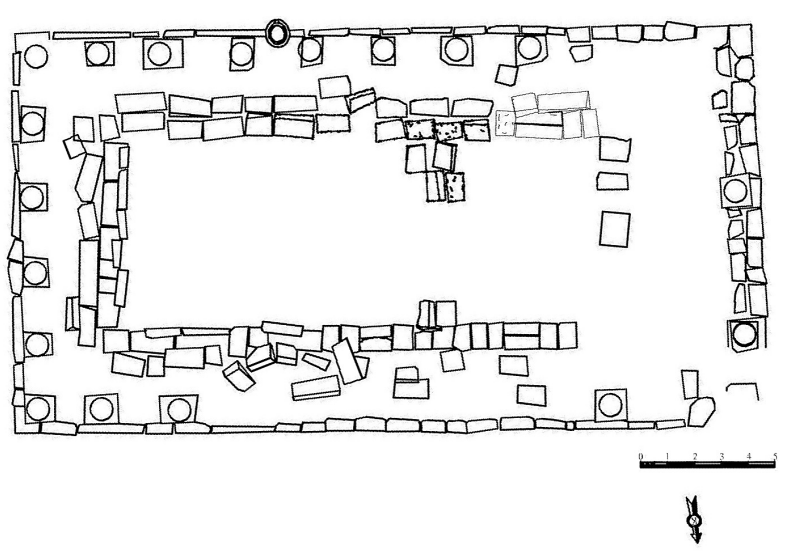

Fig. 5 : Temple of Zeus. Plan

(Alabanda archives).

rather seems to reveal a cult connected to Zeus. A second, identical, altar, was used as a spolia during the $4^{\text {th }}$ century A.D. refection of the theater's scenae (Fig. 7). It might have been brought there from the Doric temple after it had been abandoned, probably sometimes in the $3^{\text {rd }}$ century A.D. as indicated by the material revealed in the temenos.

If the temple was dedicated to Zeus, as suggested by the Labrys relief, Zeus Khrysaoris seems to be the most serious candidate. A cult dedicated to this god is known to have taken place in Alabanda': according to an inscription, dating from 203/2-202/201 B.C. and found in Delphi, a decision taken by the Amphiktion senate approves Alabanda as the private lands dedicated to Zeus Khrysaoreos and Apollo Isotimos ${ }^{10}$. Although the Labrys is most commonly associated to Zeus Labraundos, it seems that this weapon could also be associated to other epithets of Zeus, such as shown by two differtent altars, one found in Stratonikeia and belonging to Zeus Megistos, the other found in Miletos and belonging to Zeus Lepsynos ${ }^{11}$. Therefore it seems that the Labrys might have been used as a general symbol rooting to the early periods of Caria.

During the survey carried out in the immediate vicinity of the building, a pedestal carrying a labrys was discovered on the slope, west of the building, while another architectural block, also carrying a labrys, was found north of the building (Fig. 8). Those two blocks, although not found in the temenos itself, probably might have been taken from the temple area. This is supported by another discovery

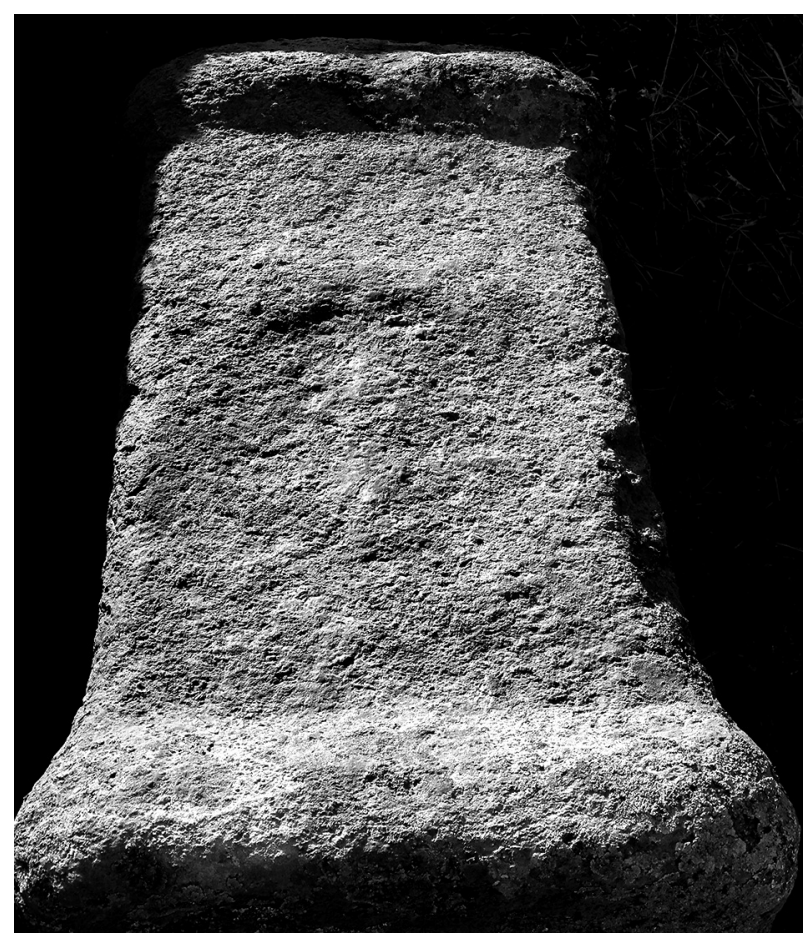

Fig. 6 : Labrys altar found in temenos (photo by author).

made during the excavation and repair work carried out in the temple. Three identical inscription " $\Delta \mathrm{I}$ " were brought to light: one on the stylobate between the seventh and eighth column drums in the north pteroma (Fig. 9), one on the stylobate block of the ninth column drum in the south pteroma (Fig. 10), and the last one on one of the architectural blocks which displaced from the temenos during the early excavations by Ethem Bey. All three inscriptions show an unusual shape for the Delta letter, which shows an asymmetrical form, indicating that they were all carved by the same individual. Considering that there are no other marks on the building, we can easily discard the possibility that these are mason marks and strongly propose to identify them as the name of the god to whom the temple was dedicated.

\section{GATHERING THE PIECES}

During the excavation, cleaning and repair works carried out in the temple, it appears clearly that each column was made of three drums. Unfortunately most of the third, upper drums were found

9) Laumonier 1958: 434-347; Cousin and Diehle 1886: 299-314; Paton 1899: 319-321; Paterson 2010: 120; Samama 2003: 564; Dmitriev 2005: 300; Bean 1980: 153.

10) Marchese 1989: 67; Cohen 1995: 248-250; Pounder 1978: 49-57.

11) Bockisch et al. 2013: 137-138, Fig. 2; Berti 2010: 63-67. 


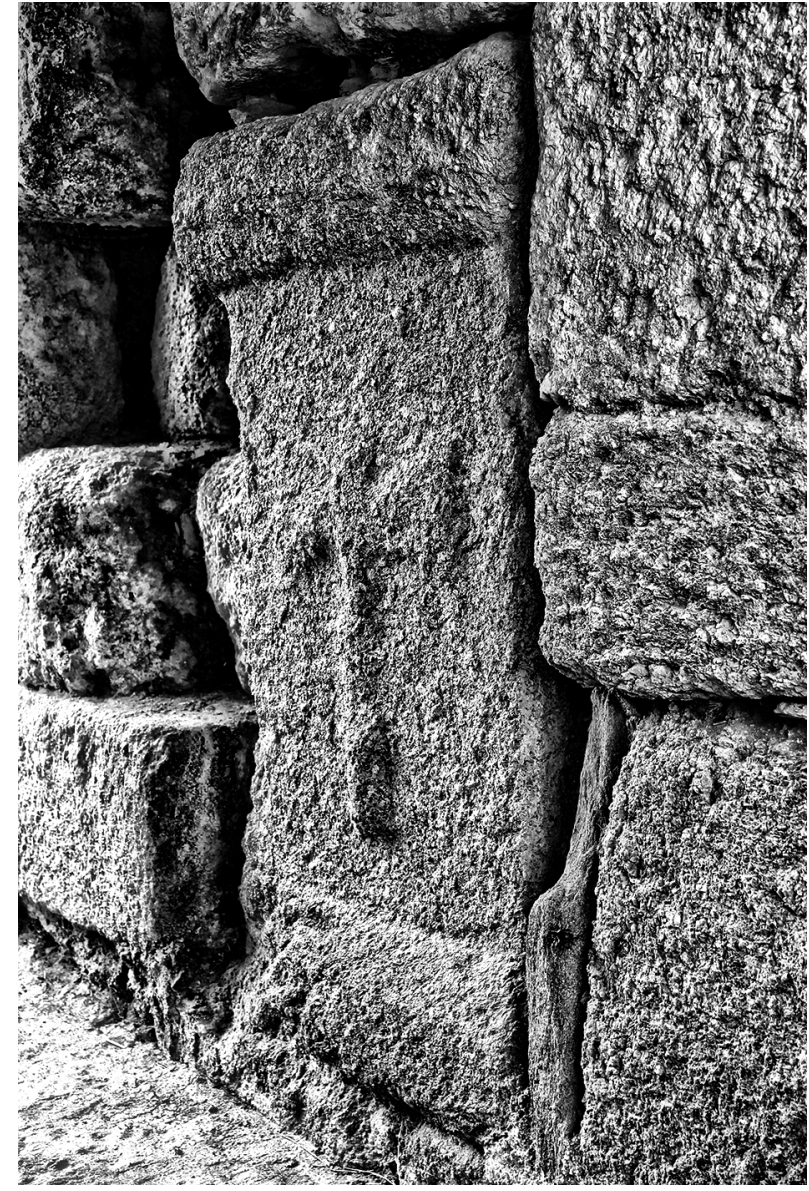

Fig. 7 : Labrys altar from Zeus Temple, re-used in the theater (photo by author).

incomplete. Beside, all the Doric column capitals seem to have disappeared from the temenos itself. Considering that many pieces of the temple have been reused in later construction, we started looking for those easily transportable capitals elsewhere on the site. We especially focused on the $4^{\text {th }}$ century A.D. colonnade of the re-built frons scaenae of the theater (Figs. 11-12). Following a detailed analysis, it quickly appeared that not only the diameter of the capitals perfectly fitted the upper diameter of the preserved third drums of the temple, but also that many of the column drums, randomly placed on the frons scaenae colonnade, had the very same dimensions as the ones uncovered in the temenos. If one adds the above-mentioned altar with labrys, it becomes clear that most of material used to re-erected the scaenae of the theater came from the temple.

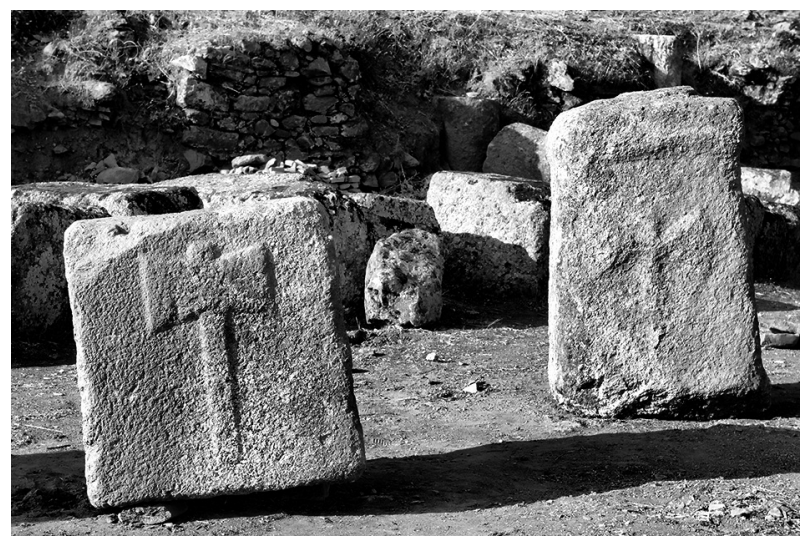

Fig. 8 : On the right, a pedestal with labrys was detected on the slope in the west of the building and on the left, an architectural block with labrys was detected in the north of the building (photo by author).

\section{GNEISS VS MARBLE}

The entire complex temple/temenos was built out of gneiss blocks, probably quarried from the immediate vicinity of the construction site. Nonetheless, the excavations of the temple have revealed many traces of stucco applied on both column drums and blocks of the naos (Fig. 13). It also points out that the building might have had several construction phases. The date of the building might indeed be quite early, as its peripteral plan having 6 x 11 column with a deep pronaos and naos without opisthodomos seems to carry on a tradition dating back to old times in Anatolia ${ }^{12}$. Local gneiss used in the temple could be easily worked out and made as smooth as requested, as shown in the $4^{\text {th }}$ century B.C. subterranean chamber tomb ${ }^{13}$. In our case, nonetheless, the surfaces were roughly carved and clearly recall a comparative workmanship such as the one seen in the Andrones at the Sanctuary of Labraunda. Although the latter had a front façade entirely made out of marble, it is highly suspected that the rest of the building was covered with stucco, which would give the appearance of marble ${ }^{14}$. The habit of using stucco over local material instead of building in marble was therefore already developed in the region in the $4^{\text {th }}$ century B.C. The remains of stucco on the Zeus temple of Alabanda might then correspond to the very same process as the one seen at Labraunda. 

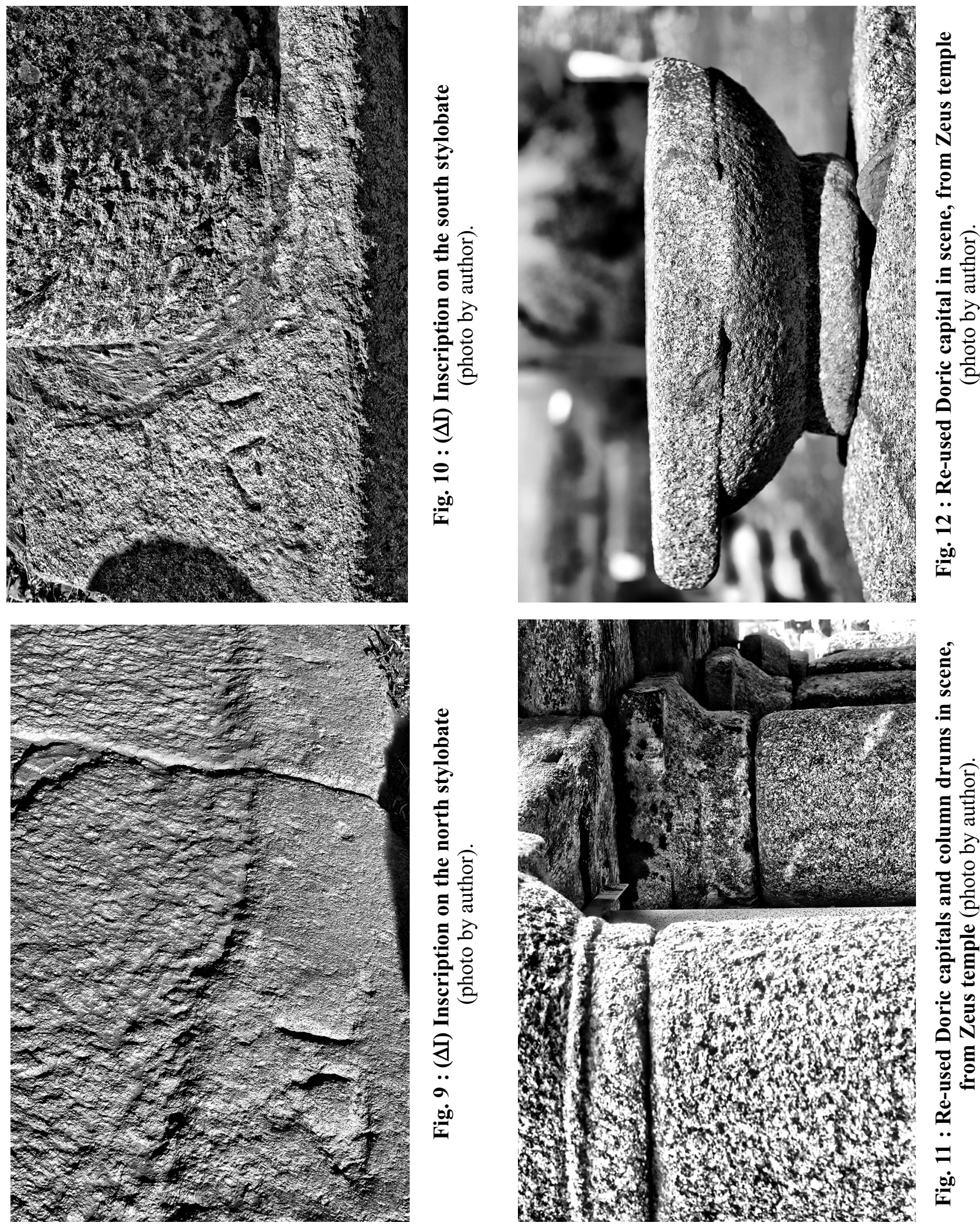


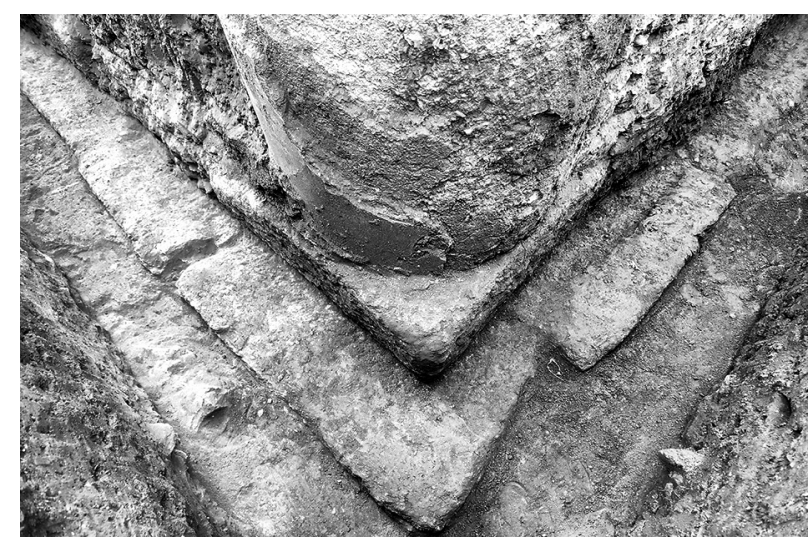

Fig. 13 : Column drum with in situ stucco at the south-east corner of the Zeus temple (photo by author).

The temple nonetheless might be much older. While excavating the naos, several Attic amphora shoulder pieces dating to the $6^{\text {th }}$ century B.C. (Fig. 14) as well as a great number of Attic black glazed potteries dating to the $5^{\text {th }}$ and $4^{\text {th }}$ centuries B.C. were uncovered. This material clearly seems to have been found in situ and not coming from the slope of the hill, indicating therefore that first phase of the building might be from Classical period, if not Archaic.

\section{STONE VS WOOD}

The excavation of the building revealed a surprising characteristic. It appeared that none of the original floors was made of stone slabs but rather out of the bedrock (sometimes even barely leveled), as in the naos and pronaos, or by using a layer of rubble covered by packed soil, as in the pteron. This construction technique seems quite unusual and might reveal some kind of wooden architecture tradition, for which only the wooden columns (later replaced by stone) would have needed a strong stone foundation, as is the case in Alabanda. Also, considering the rough bedrock ground of both the naos and pronaos it is highly probable that their floor were made of wooden planks and/or packed soil.

Scholars have recently emphasized the wooden architecture tradition in Karia, through analysis of stone architecture ${ }^{15}$. Starting from the Classical funerary architectural tradition in Lykia, translating in stone a fine wooden architecture ${ }^{16}, \mathrm{O}$. Henry could prove that some of the $4^{\text {th }}$ century B.C. Karian monumental (subterranean) tombs could clearly be traced

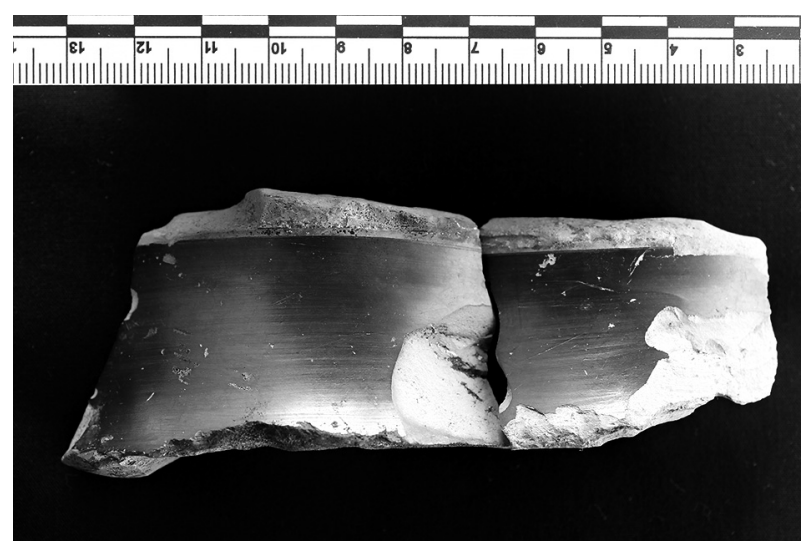

Fig. 14 : Attic amphora fragment from shoulder, found in the naos (photo by author).

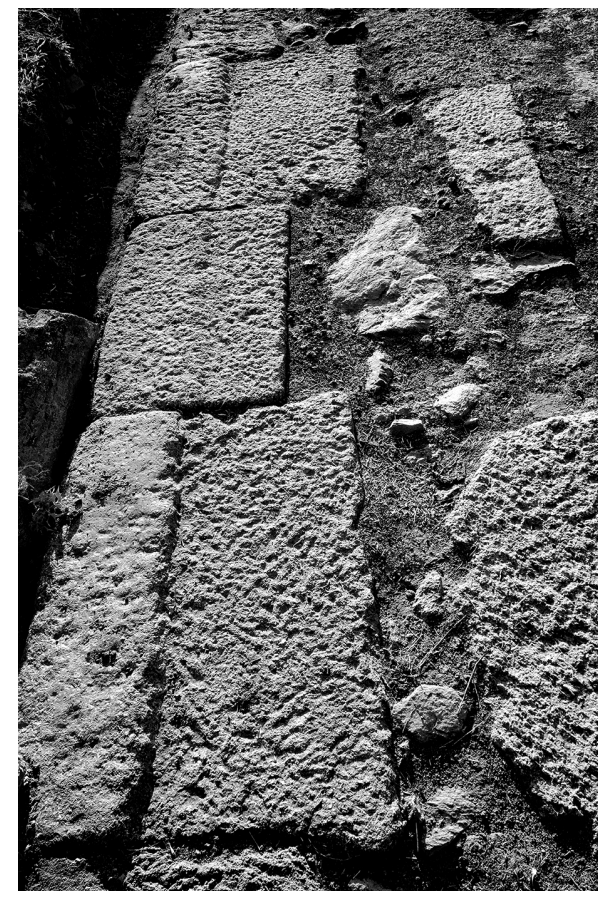

Fig. 15 : Euthynteria of the Temple (photo by author).

to an earlier wooden architecture. The latter can be detected at least in the late $6^{\text {th }}$ century Beçin monumental tomb, which seems to be the earliest example of the widely spread, although short lived, $4^{\text {th }}$ century B.C. "subterranean chamber tomb with beam".

The phenomenon raised by $\mathrm{O}$. Henry concerning funerary architecture brings forward the question of petrifaction in monumental, temple architecture in Karia; a phenomenon already largely analyzed in mainland Greece ${ }^{17}$.

15) Henry 2010a: 296-315; 2010b: 100-101; 2013: 85-86, Fig. 6-7.

16) Mühlbauer 2007.

17) Hellmann 2002: 133-135. 
Alabanda shelters one of the tombs considered by $\mathrm{O}$. Henry as carrying traces of the architectural petrifaction ${ }^{18}$. It seems therefore that this transformation from wooden to stone architecture was not unusual in the city and that they might very well also reflect in the Zeus Temple. As we mention above, preferring soil ground in the pteron, while having a series of stone blocks under the columns might have been a practice only preferred in the periods when the columns were made of wood.

The cleaning of the temple also revealed the irregularity of the construction of the euthynteria. Indeed, while some blocks show a clean and smoothly carved backside, their upper side shows a rough craftsmanship, indicating that they seem to have been flipped over when put in place (Fig. 15).

Along the northern side of the temple terrace excavations have revealed the presence of the substructure of a wall built in the very same fashion as the temple's euthynteria and reusing blocks from an older building. This wall seems to form the stylobate of a stoa (one drum of a column has been found in situ) opened toward the inside of the temenos space. This kind of structures are not unknown in Asia Minor. One might mention a similar case in Priene, designed by the architect Pytheos of Caria ${ }^{19}$. While in Priene the stoa faced the Meander River and turned its back to the temple, in Alabanda it is understood that the stoa faced the temple of Zeus.

\section{RESTORING THE TEMPLE}

After having excavated the temple of Zeus, our activity focused on rearranging its members. Indeed, compared to photos taken by Halil Ethem Bey's it is clear that the structure had suffered a lot after it was excavated and exposed to open air for more than a century. With the help of the documentation from the old excavations, we started restoring the architectural members of the temple, i.e. replacing tilted blocks from the wall of the naos and the lower drums of columns from the pteron into their original place, when known with certainty. In this matter, the $5^{\text {th }}$ and $8^{\text {th }}$ column drums (from west) on the south side, the $5^{\text {th }}$ column drum (from the south) on the east side, and the $4^{\text {th }}$ column drum (from south) on the west side were raised again.

The Doric Zeus Temple in Alabanda, birthplace of the famous architect Hermogenes ${ }^{20}$, had a very important place in terms of architecture history in $4^{\text {th }}$ century Caria where architecture and sculpture Pytheos lived and where witnessed a Renaissance ${ }^{21}$. It is therefore important to try to give it its original shape by not only excavating and analyzing but also by protecting, conserving and, if possible, by restoring its structure. A multiple task that already started and which will intensify in the coming years.

S.A.

\section{BIBLIOGRAPHY}

Ateşlier, A., 2012: “Alabanda, Karia'nın Mimarlar Kenti”, Aydın Kültür ve Turizm Dergisi 4: 78-84.

Akarca, A., 1952: "Mylasa'da Hellenistik Bir Mezar", Belleten XVI: 367-405 don.

Bean, G.E., 1980: Turkey Beyond the Meander, Lon-

Berti, F., 2010: "İasos, Çifte Balta ve Zeus / Iasos, Labrys and Zeus", in Kuzucu, F. and Ural, M. (eds.), Mylasa, Labraunda, Milas, Çomakdă̆. Güney Ege Bölgesi'nde Arkeoloji ve Kirsal Mimari, İstanbul: 63-67.

Cohen, G.M., 1995: The Hellenistic Settlements in Europe, the Island, and Asia Minor. Oxford.

Cousin, G. and Diehl, Ch., 1886: "Inscriptions d'Alabanda en Carie", BCH X: 299-314.

Delattre, A.F., 1906: "Le cimetière chrétien de Mcidfa à Carthage", CRAI 50: 1-13.
Dmitriev, S., 2005: City Goverment in Hellenistic and Roman Asia Minor, Oxford.

Ethem Bey, H., 1905: "Fouilles d'Alabanda en Carie. Rapport sommaire sur la première campagne", CRAI 49: 443-459.

- 1906: "Fouilles d'Alabanda. Rapport sommaire sur la seconde campagne (1905)", CRAI 50: 407-422.

Hellmann, M.-Chr., 2002: L'architecture grecque 1.

Les principes de construction, Paris.

Hellström, P., 2007: Labraunda, İstanbul.

Henry, O., 2010a: "Wood Reflections on Stone Tombs in Southwest Asia Minor", in Summerer, L. and Von Kienlin, A. (eds.), Tatarl, Return of Colours. İstanbul: 296-315.

- 2010b: "Labraunda Nekropolü / Necropolis of Labraunda", in Kuzucu, F. and Ural, M. (eds.), Mylasa,

18) Henry 2010a.

19) Rumscheid 2000: 108-109, Fig 90.

20) Vitruvius III.2.6.

21) Pedersen 2013: 33-64; Henry 2013: 81-90; Karlsson 2013: 65-80. 
Labraunda, Milas, Çomakdağ. Güney Ege Bölgesi’nde Arkeoloji ve Kırsal Mimari. İstanbul: 93-105.

- 2013: "A Tribute to the Ionian Renaissance", in Henry, O. (ed.), $4^{\text {th }}$ Century Karia. Defining a Karian Identity Under the Hekatomnids [Varia Anatolica XXVIII], İstanbul: 81-90.

Hirschfeld, G., 1893: “Alabanda”, RE I.1: 1270.

Karlsson, L., 2013: "Combining Architectural Orders at Labraunda: A Political Statement", in Henry, O. (ed.), $4^{\text {th }}$ Century Karia. Defining a Karian Identity Under the Hekatomnids [Varia Anatolica XXVIII], İstanbul: 65-80. Laumonier, A., 1958: Les Cultes Indigénes en Carie, Paris.

Marchese, R.T., 1976: A Historical of Urban Organization in the lower Meander River Valley: Regional Settlement Patterns to the Second Century A.D. New York University \& Ann Arbor, Michigan.

Mühlbauer, L., 2007: Lykische Grabarchitektur, Wien.

Paton, W.R., 1899: “Antiochia Chrysaoris”, Classical Review 13.6: 319-321.

Patterson, L.E., 2010: Kinship myth in ancient Greece, University of Texas Press.

Pedersen, P., 2013: “The $4^{\text {th }}$ century B.C. 'Ionian Renaissance' and Karian identity", in Henry, O. (ed.), $4^{\text {th }}$ Century Karia. Defining a Karian Identity Under the Hekatomnids [Varia Anatolica XXVIII], İstanbul: 33-64.

Bindokat, A.P., 2006: Tarih Öncesi Insan Resimleri. Latmos Dağlarl'ındaki Prehistorik Kaya Resimleri, İstanbul.
Pounder, R.L., 1978: "Honors for Antioch of the Chrysaoreans", Hesperia 47.1: 49-57.

Rumscheid, F., 2000: Küçük Asya'nın Pompeisi Priene. İstanbul.

Samama, E., 2004: Les médecins dans le monde grec : Sources épigraphiques sur la naissance d'un corps médical, Genève.

Serdaroğlu, Ü., 2004: Lykia-Karia'da Roma Dönemi Tapınak Mimarlığl. İstanbul 2004.

Westholm, A., 1963: Labraunda. The Architecture of the Hieron, Lund.

Yener, E., 2001: “Alabanda Antik Kenti Kazı, Temizlik ve Çevre Düzenleme Çalışmaları 1999”, 11. Müze Çalışmaları ve Kurtarma Kazıları Sempozyumu. Denizli 2000, Ankara: 5-16.

- 2002: "Alabanda Antik Kenti Kazı, Temizlik ve Çevre Düzenleme Çalışmaları”, 12. Müze Çalışmaları ve Kurtarma Kazıları Sempozyumu. Kuşadası 2001, Ankara: 179-190.

- 2005: “Alabanda Antik Kenti Kazı, Temizlik ve Çevre Düzenleme Çalışmaları”, 14. Müze Çalışmaları ve Kurtarma Kazıları Sempozyumu Nevşehir 2004, Ankara: 117-124.

- 2006: "Alabanda Antik Kenti Kazı, Temizlik ve Çevre Düzenleme Çalışmaları 2005”, 15. Müze Çalışmaları ve Kurtarma Kazlları Sempozyumu, Kuşadası 2006, Ankara: 171-180. 


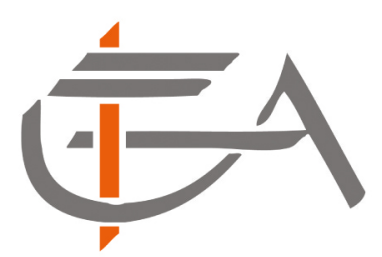

Institut Français

d'Etudes Anatoliennes

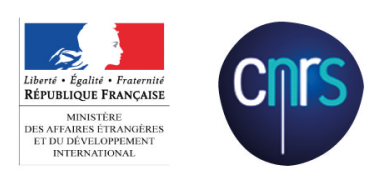

Peinture rupestre préhistorique, Sağlık Köy, près d'Alabanda, Turquie (cliché Suat Ateşlier). 